\title{
ICT IN THE CONSTRUCTION SECTOR: COMPUTING THE ECONOMIC BENEFITS
}

\author{
Les RUDDOCK \\ Research Institute for the Built and Human Environment, University of Salford, M5 4WT, U.K. \\ E-mail: L.Ruddock@salford.ac.uk
}

Received 2 May 2005; accepted 3 August 2005

\begin{abstract}
Any assessment of the extent of the economic benefits for the construction sector from technological change is difficult to determine accurately but in view of the construction sector's contribution to a nation's economy, it is important that the impact of technological change on the industry is properly recognised. One area of technological change in the industry - the increased use of information and communication technology (ICT) is considered in this study, which examines the evidence concerning the crucial role of ICT usage and investment in generating growth and improving technical productivity in the industry and considers the question of how the gains from ICT can be evaluated at the industry level. The U.K. construction sector forms the focal point of this study but comparisons are also made with the construction sectors of other industrially developed countries. The results of the analysis find that the construction industry is now beginning to reap the benefits on productivity from the post - 1995 surge in ICT investment.
\end{abstract}

KEYWORDS: Construction industry; Efficiency measurement; ICT; Technological change

\section{INTRODUCTION}

In recent years, the rapid growth in ICT production and investment has been an important contributor both to economic and productivity growth in U.K. industry. In addition, ICT investment has added to the U.K. capital stock and capital services, with longer-term effects on the U.K. economy.

Using data from the U.K. 1992-2003 InputOutput Supply and Use Tables (ONS, 1992, 1996, 2000, 2002, 2003), Figure 1 illustrates how growth (in real terms) in the ICT sector has been a major feature of the U.K. economy. Gross Value Added (GVA) - an accepted basis for measuring contributions to the economy rose twice as fast in the ICT sector over the decade as the average for all industries and, indeed, approximately four times as fast as the rate for the construction industry.
The benefits from investment and use of ICT in the construction industry are expected to show themselves as improved efficiency and productivity but an evaluation of the economic benefits for the construction sector is notoriously difficult to accurately determine. Whilst researchers analysing the benefits from ICT use and investment have tended to concentrate their assessment at the firm/organisation level, studies at the industry level have been scarce (Skibniewski and Park (2004) provide a comprehensive review of prior studies of the impact of ICT investment on performance, especially at the firm level).

The construction industry certainly is not amongst the foremost industries in its use of many categories of ICT but the significance of the efficiency gains from the use of ICT in the construction sector still needs to be understood.

In a review of the evaluation of these gains, 


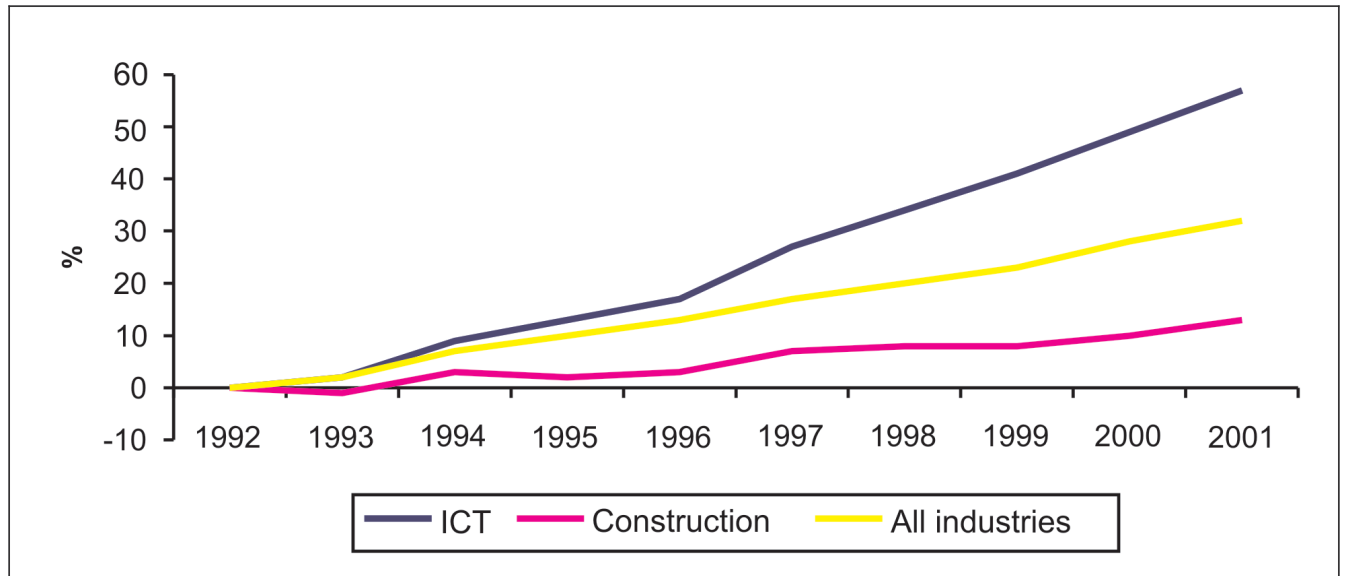

(Source: Derived from ONS: U.K. Input-Output Analyses 1992-2003)

Figure 1. GVA: ICT and Construction industry growth compared to all industries in the U.K. economy (\% growth in real terms based on 1992)

the major part of this paper concerns itself with attempting to answer a series of questions, viz:

- How is the ICT sector defined?

- How does the construction industry compare to others in its adoption and use of ICT?

- What is the contribution of ICT to economic growth in the industry?

- How can the gains from ICT be evaluated in terms of industry productivity and technical efficiency?
- Why has the 'pay-off' from investment in ICT not been greater?

- Is there a productivity gap between the U.K. and its competitors?

\section{HOW IS THE ICT SECTOR DEFINED?}

A prerequisite for evaluation is to consider how the ICT sector is defined in terms of economic measurement. A definition of the ICT sector was agreed by the Organisation for Eco-

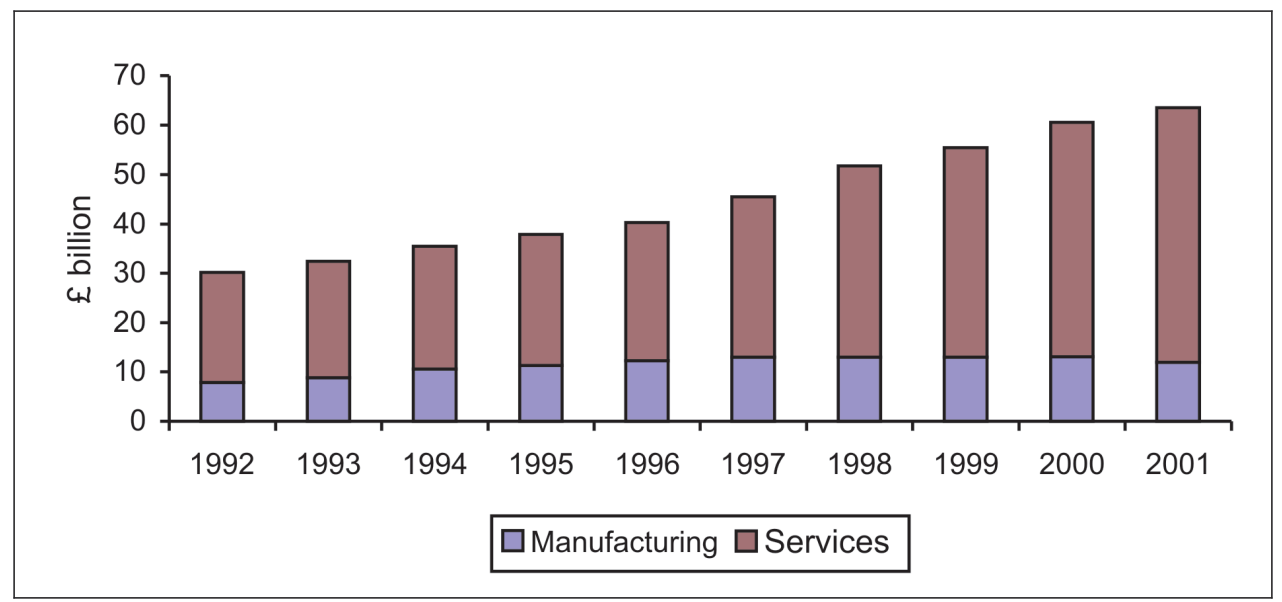

(Source: Derived from ONS: U.K. Input-Output Analyses 2003)

Figure 2. ICT GVA: Manufacturing and services sector contribution 
nomic Cooperation and Development (OECD) Committee for Information, Computer and Communications Policy (ICCP) in 1998 and updated in a paper by the OECD Secretariat in 2002 on 'Measuring the Infrastructure Economy' (OECD, 2002).

The definition distinguishes between goods (such as office machinery and communication equipment) and services (such as telecommunication including transmission and display) based on the following:

Products in the manufacturing industries (ONS, 2003):

- Must be intended to fulfil the function of information processing and communication including transmission and display.

- Must use electronic processing to detect, measure and/or record physical phenomena or to control a physical process.

Products in the service industries:

- Must be intended to enable the function of information processing and communication by electronic means.

Figure 2 shows the relative importance of these two parts of the sector, in terms of their GVA contribution to the U.K. economy, and in- dicates that growth has been led by the service industries rather than manufacturing industries. Between 1992 and 2001, the services component grew by $131 \%$ whereas the manufacturing component grew by $51 \%$.

Figure 3 displays a breakdown of selected industries incorporated in the ICT definition and their change in contribution to GVA at current basic prices between 1992 and 2001. Most of the industries have grown, with the largest growth in the computer services and telecommunication industries. The office machinery area, however, peaked in 1997 and has continued to fall in each subsequent year.

\section{HOW DOES THE CONSTRUCTION INDUSTRY COMPARE TO OTHERS IN ITS ADOPTION AND USE OF ICT?}

The adoption of information technology by industry in general has brought about major changes in the way business is conducted. However, the adoption of ICT by the construction industry has not been as significant as in other sectors. The reasons for the industry's low usage have been the subject of several

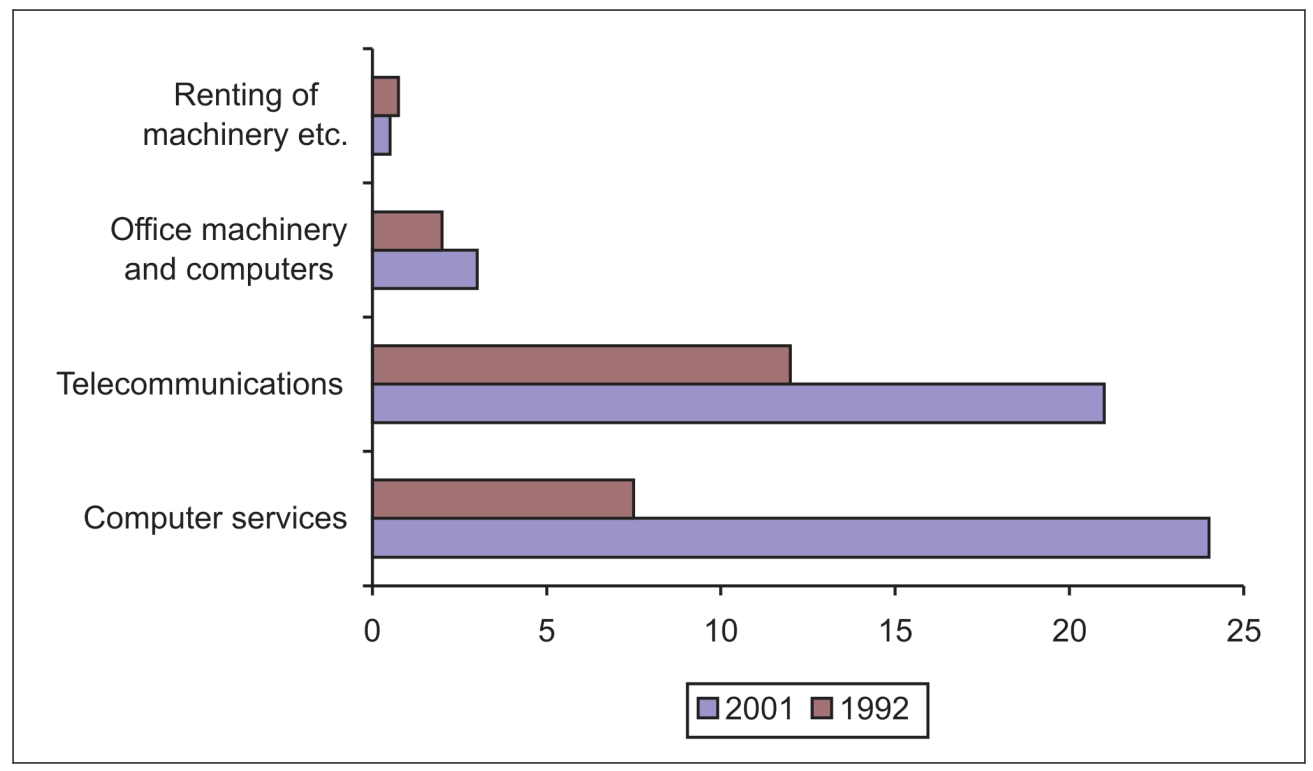

(Source: Derived from ONS: U.K. Input-Output Analyses 1992-2003)

Figure 3. GVA contribution by selected areas (£ billion) 
studies. (See, Li et al. (2000) for a review of studies at the organisational level).

\subsection{U.K. evidence}

There has been concern for the last two decades that the construction industry has lagged behind other sectors in its take-up of new technology. A survey of U.K. industry in 1990 (CICA, 1990) showed that, whilst the 1980s had been a period of rapid technological change, this did not result in major investment by the construction sector in comparison to a selection of other industry areas, as indicated in Table 1.

Table 1. Percentage of turnover spent on IT by industry sector (1985-90)

\begin{tabular}{ll}
\hline & $\%$ \\
\hline Construction & $\mathbf{0 . 4}$ \\
Manufacturing & 1.5 \\
Retailing & 1.6 \\
Government & 2.8 \\
Finance & 6.6 \\
\hline
\end{tabular}

(Source: Building on IT for the 90s: A Survey of IT Trends and Needs in the Construction Industry. CICA, 1990)

Table 2. Use of computer services (by industry) 2002

\begin{tabular}{ll}
\hline Industry & $\%$ \\
\hline Construction & $\mathbf{0 . 4}$ \\
Retailing & 1.0 \\
Architectural activities & 2.4 \\
Real estate and lettings & 7.9 \\
All industries & 1.0 \\
\hline
\end{tabular}

(Source: Derived from the U.K. Input-Output Tables 2003)

In the period since that survey, concerns over the apparent inability or unwillingness of the industry to take advantage of new technologies still exist and the low level of expenditure by the industry persists. From the U.K. Input-Output tables for 2002 (ONS, 2003), the percentage of inputs acquired from the Computer Services sector - based on the standardised OECD definition - can be calculated and a $0.4 \%$ level for the construction sector appears to indicate a degree of consistency, when looked at in conjunction with the 1990 survey. Table 2 allows comparison to be made between the construction industry itself and the related sectors of architectural activities and real estate. The latter sector, in particular, is one in which expenditure on ICT services has been an important feature.

\subsection{Evidence from the U.S.}

This also points to a low level of importance in the relative contribution of ICT in investment in the construction sector. Data from the Bureau of Economic Analysis (BEA) (2004) can be used to assess the extent of IT equipment stock as a proportion of total capital stock across a variety of U.S. industry sectors.

From Figure 4 it can be seen that ICT investment is much less intensive in construction than the service sectors and slightly less so than in manufacturing. Service sectors are typically the most intensive investors in ICT.

Typically, too, the BEA data indicate that the distribution of ICT also differs according to the size of firms. Smaller firms tend to be less ICTintensive than large firms. Partly because large firms have more scope for improving communication flows within the organisation and partly because large firms also invest more in ICT than small firms as ICT investment is risky and uncertain, which may be more difficult for small firms to bear. The fragmented nature of the construction industry (in the U.S. as in the U.K.) is obviously a major consideration for the construction sector here.

\section{WHAT IS THE CONTRIBUTION OF ICT TO ECONOMIC GROWTH IN THE INDUSTRY?}

The last quarter of a century has been a period of rapid technological change but this has not necessarily shown itself in economic or productivity growth. The measurement of the contribution of ICT to the productivity of the construction industry is fraught with difficulty. Investment in ICT makes a contribution to future productivity potential through the capital services yielded by ICT and the 


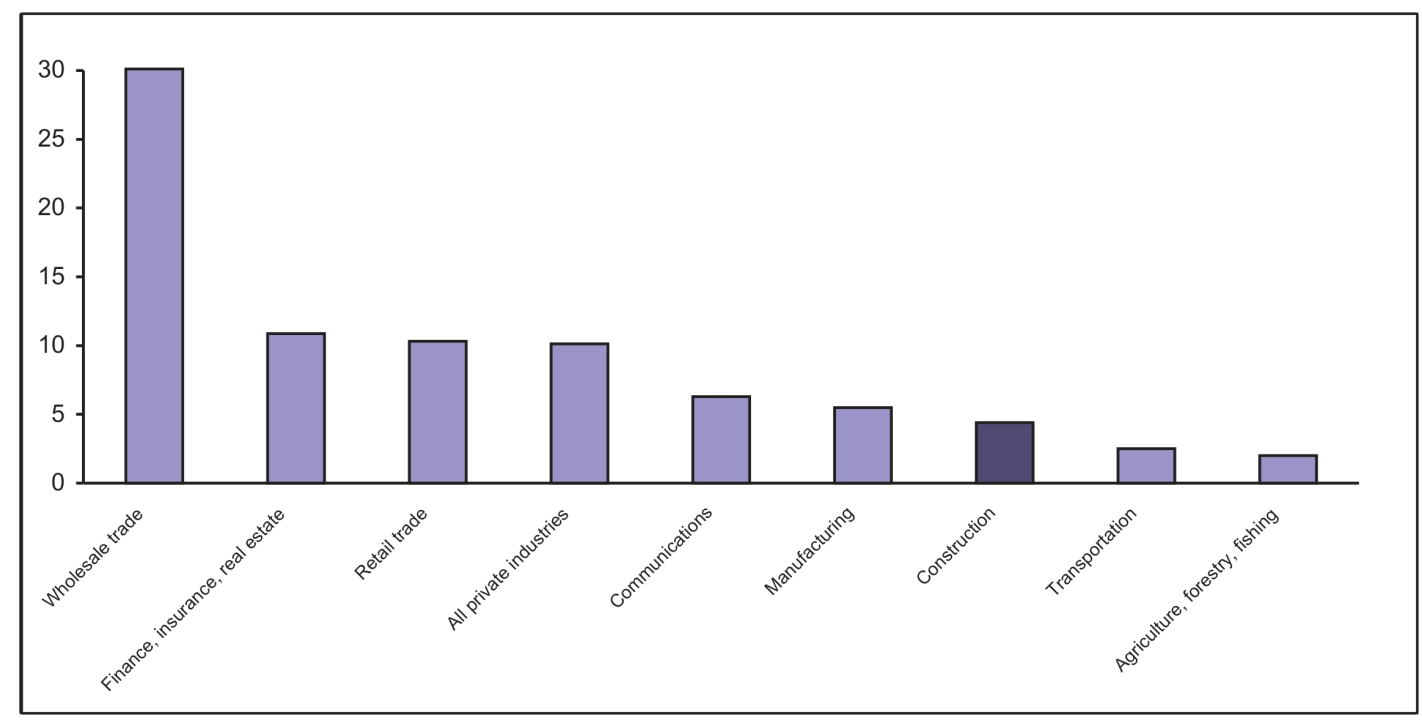

Source: Adapted from Bureau of Economic Analysis, US Department of Commerce - Fixed Asset Tables (2004) (www.bea.doc.gov)

Figure 4. Information technology as a percentage of all stock of equipment and software. United States, 2001

modernisation of the capital stock. As in other countries, the U.K.'s Office of National Statistics (ONS) is working to improve the measurement of capital stock and the ONS is working together with the Bank of England to develop a volume index of capital services.

Concern has been expressed that U.K. productivity growth has not been as strong as expected, given the growth in ICT activity. Rapid investment is usually accompanied by strong growth in productivity but it takes time for the implementation of new technology to realise its full potential. For example, old processes to make old products are re-engineered to- gether with restructuring the business before real gains are achieved. The time span needed to achieve productivity gains means that, although these may not immediately be visible, an industry may achieve stronger productivity gains over the ensuing few years.

The U.K. Input-Output tables break the whole economy down into 123 industry areas and each industry area can be ranked according to its relative contributions to GVA. Whilst construction remains close to the top of the rankings in terms of GVA (although it fell from third to fourth position between 1992 and 2001), it was only thirty-ninth in terms of growth over the period (Table 3 ).

Table 3. Change in contribution by industry to GVA between 1992 and 2001

\begin{tabular}{|c|c|c|c|c|c|c|c|c|}
\hline \multirow[t]{2}{*}{ Industry } & \multicolumn{2}{|c|}{$\begin{array}{l}\text { GVA at basic prices } \\
\text { (£m) }\end{array}$} & \multicolumn{2}{|c|}{$\begin{array}{l}\text { GVA as a } \% \text { of total } \\
\text { GVA }\end{array}$} & \multicolumn{2}{|c|}{$\begin{array}{l}\text { Change in GVA } \\
\text { between } 1992 \text { and } \\
2001\end{array}$} & \multicolumn{2}{|c|}{ Ranking position } \\
\hline & 1992 & 2001 & 1992 & 2001 & $£ \mathrm{~m}$ & $\%$ & By $£ \mathrm{~m}$ & By \% growth \\
\hline Construction & 30020 & 50218 & 5.49 & 5.70 & 20198 & 67.3 & 4 & 39 \\
\hline $\begin{array}{l}\text { All industries } \\
\text { (123 total) }\end{array}$ & 546434 & 880904 & 100 & 100 & 334470 & 61.2 & - & - \\
\hline
\end{tabular}

(Source: Derived from the U.K. Input-Output Tables 2003)

(Note that the percentage growth for construction of sixty seven per cent is in 'monetary' terms - not the growth in 'real' terms depicted in Figure 1). 
Table 4 shows a selection of the 123 industries ranked in terms of GVA growth over the period.

The computer services industry itself is, unsurprisingly, the industry sector with the highest growth rate. Generally, the business and management industries with a strong input of ICT services figure in the top-ranking positions. At the other extreme are the heavy manufacturing industries of the economy, now in rapid decline. The construction industry lies towards the top of the middle-ranking industries.

\subsection{The crucial role of ICT investment in economic growth}

Trends in various economies have been difficult to detect, partly due to discrepancies among official price indices for ICT equipment and software (Wyckoff, 1995). Schreyer (2000) constructed 'internationally harmonised' ICT prices, which eliminate many of these discrepancies. Employing internationally harmonised prices like those constructed by Schreyer, Jorgenson (2003) separated the contribution of capital input to economic growth into ICT and non-ICT components and came to the conclusion that internationally harmonised prices for ICT equipment and software are essential for capturing differences for international comparisons.
He has calculated the contribution of capital input to economic growth for the G7 nations divided between ICT and non-ICT over the period 1980-2000, split into three distinct periods: $1980-88,1989-95$ and 1995-2000 - after 1995, the growth rates of ICT capital stock surged in the U.K. as in all the G7 countries. Also, the growth rate for ICT capital reflects the rates at which shorter-lived ICT assets are substituted for longer-lived assets.

When the two capital input contributions for the whole economy are adjusted to reflect the relative differences for the construction industry, Figure 5 presents the contribution of capital input to growth in the industry for the three periods. Due to the availability of detailed Input-Output data only for specified years for the U.K. economy, the years 1988, 1992 and 1996/ 2000 are used as proxies for the three periods.

The evidence appears to indicate that the surge in ICT capital in the industry post-1995 is reflected by a significant change in the resultant growth attributable to ICT investment.

\section{HOW CAN THE GAINS FROM ICT BE EVALUATED IN TERMS OF INDUSTRY PRODUCTIVITY AND TECHNICAL EFFICIENCY?}

The famous remark by Robert Solow (1987) that "you see computers everywhere but in the productivity statistics" was still pertinent in

Table 4. Ranking of industries by \% growth

\begin{tabular}{lll}
\hline Industry & \% growth $(1992-2001)$ & Ranking out of 123 industries \\
\hline Computer services & 280 & 1 \\
Recycling & 261 & 2 \\
Business services & 183 & 4 \\
Management consultancy & 181 & 5 \\
Advertising & 169 & 6 \\
Construction & 67 & 39 \\
Iron and steel & -43 & 120 \\
Leather goods & -46 & 121 \\
Coal extraction & -77 & 122 \\
Metal ores extraction & -99 & 123 \\
\hline
\end{tabular}

(Source: Derived from the U.K. Input-Output Tables 2003) 


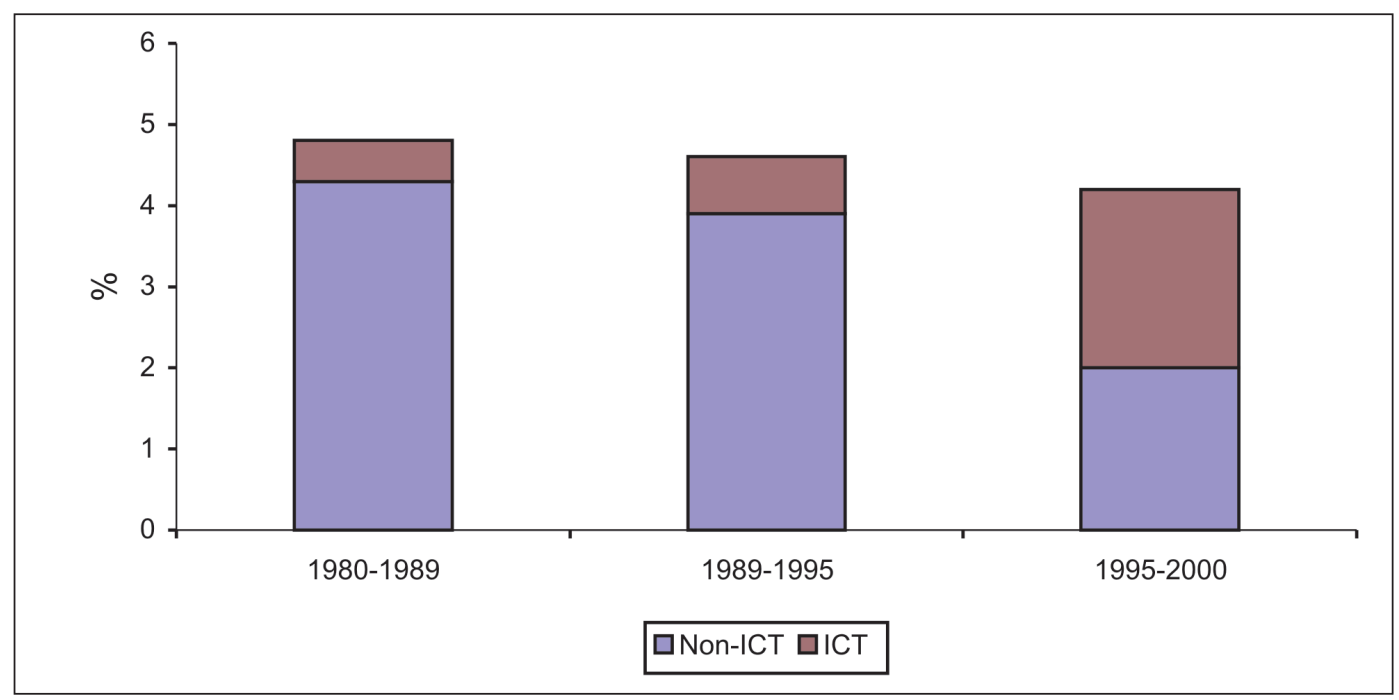

Figure 5. Capital input contribution (ICT and non-ICT) to growth for the U.K. construction sector

the early $1990 \mathrm{~s}$, when the rapid diffusion of computing technology seemed to have little impact on productivity growth.

Empirical research into the relationship between ICT investment and productivity in the 1990s did not generally find productivity improvements associated with ICT investment (Becchetti et al., 2003). Some empirical investigations have found evidence that ICT is associated with improvements in productivity and in economic growth (Lehr and Lichtenberg, 1999), but other studies stressed the potential negative effect of augmented variety on productivity, the delayed effect of ICT investment on productivity gains and its dependence on network externalities and on changes in the complementary infrastructure (David, 1990).

Battese and Coelli (1998) analysed the determinants of ICT investment and the impact of information technology on productivity and efficiency on a representative sample of SMEs in Italy.

In order to test the most relevant theoretical predictions from the ICT literature, they evaluate the impact of investment in software and hardware of the firms on a series of intermediate variables and on productivity. Among intermediate variables, they consider the de- mand for skilled workers, the introduction of new processes and products and the rate of capacity utilisation. Among productivity measures, they include total factor productivity, labour productivity and the distance from the 'best practice' by using a stochastic frontier approach.

Their results showed that the effect of ICT investment on firm efficiency could be more clearly detected at firm level by data by decomposing it into software and telecommunications investment. They found that telecommunications investment positively affects the creation of new products and processes, while software investment increases the demand for skilled workers, average labour productivity and proximity to the optimal production frontier. They interpreted the results to mean that ICT investment modifies the trade-off between scale and scope economies.

\subsection{Are some ICT technologies more important than others in enhancing productivity in the construction sector?}

Communication network technologies are particularly important for some sectors. An Australian study, based on firm-level data (Gretton et al., 2002), showed that ICT had a 
positive effect on multi-factor productivity (MFP) growth in the 1990s before the peak in ICT investment but that there was considerable variation across industry sectors.

Figure 6 enables a comparison between the construction sector and other sectors. The work processes of the construction sector mean that the importance of computer use interactions are specifically emphasised in this sector.

In Italy, Milana and Zeli (2001) investigated how ICT affects production performance and technical efficiency. The construction industry was one of the industries, in which they found a correlation between ICT and technical efficiency, defined on the basis of R\&D intensity of production.

They presented a firm-level analysis of the productivity slowdown that had been observed in Italy. Data Envelopment Analysis (DEA) techniques were applied to firm-level data and total factor productivity (TFP) changes for the years 1996-99 were measured. The analysis uses a frontier method as a means of measuring efficiency with efficient organisations operating on the production frontier.

The method involved the use of DEA, a linear programming technique, to determine a production frontier consisting of the most efficient production points in a space of output and inputs and using DEA results. The Malmquist index of TFP growth (defined by Caves, Christensen and Diewert, 1982) was constructed, and these indexes can be decomposed into changes in the firms' distance from the efficient frontier (technical efficiency changes) and the shift of the frontier itself (technological change). Färe, Grosskopf, Norris and Zhang (1994) provide a detailed explanation of the use of DEA techniques. The change for each industry was decomposed into technological change (shift in the production frontier) and change in relative technical efficiency (due to modifications in the distance of the single firms from the frontier).

Econometric regressions of the firms' TFP changes on a number of variables, including a component factor correlated to ICT, revealed that the information and communication technologies may have had a positive and significant impact on TFP in all the examined industries during the period. They found that the impact of ICT on TFP was relatively strong in the construction industry, even though it was not a particularly ICT-intensive user.

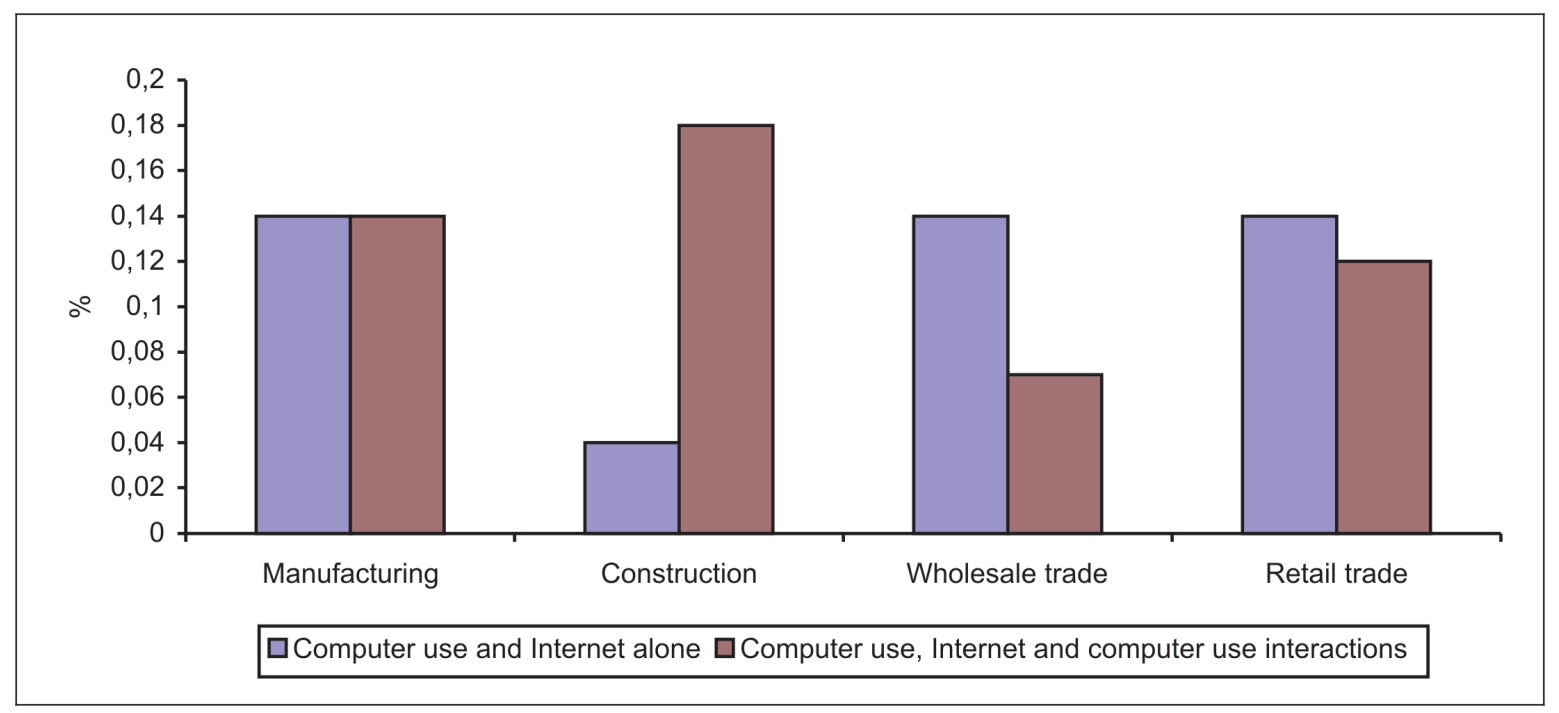

(Source: Adapted from Gretton et al (2002))

Figure 6. Estimated contribution of ICT to multi-factor productivity growth in Australia (1994-5 to 1997-8) 
Basu et al. (2003) indicated that unmeasured investments in intangible organisational capital, associated with the role of ICT as 'general purpose technology' (GPT) can explain divergent U.S. and U.K. TFP performance after 1995. They suggested that measured TFP should rise in ICT using sectors, perhaps with long lags. Contemporaneously, investments in ICT may in fact be associated with lower TFP as resources are diverted to reorganisation of learning. In the U.S. and the U.K., they find a strong correlation between ICT use and industry TFP growth. In the U.S. in particular, results show that TFP acceleration was located primarily in ICT-using industries and is positively correlated with industry ICT capital growth.

In many sectors of the U.K. economy, TFP growth does not appear correlated with lagged ICT capital growth. But TFP growth in the late 1990s is strong and positively associated with the growth of ICT capital services, while being strongly associated with the growth of ICT investment. This strengthens the previously mentioned conclusion (discernable from Figure 5), concerning the effects of the surge in ICT investment in the construction sector post1995.

\section{WHY HAS THE 'PAY-OFF' FROM INVESTMENT IN ICT NOT BEEN GREATER?}

Taking a broad view of businesses across industries, Hochstrasser and Griffiths (1991) concluded that, in the early 1990 s, there was no clear evidence of a relationship between IT investment and company performance. When considered over the longer period, it is surprising that electronic investment has not paid off with greater productivity growth in the construction industry. Possible explanations are short-term inefficiency of resource use (due to, for instance, temporary learning costs) and improvements in working conditions rather than productivity improvements.

Several reasons have been put forward sug- gesting why electronic investment has not paid off in greater productivity growth in the construction sector:

- Major changes in technology can make productivity worse before it gets better. People have to be retrained and initially the new technology is used in an unfavourable portion of the learning curve.

- The competitive advantage gained from information acquisition and processing by one company may take profits or capital gains away from other companies. If ICT is used extensively in ways that redistribute wealth rather than increase it, then their productivity effects will be reduced.

- There may be a trade-off between improved working conditions and wage payments, with the latter held down as a compensating differential for improved job satisfaction.

- The final point, and the one that is most directly related to this paper, is that computers and related equipment may be providing valuable services to customers that are not being picked up in the official output data. Deflators for consumer expenditures on service do not adequately capture quality improvements created by computers.

\subsection{International comparisons}

Whilst the previous data relate specifically to the U.K. experience, international comparisons would point to the situation being typical for industrially developed countries. Growth in ICT capital input per capita rose to doubledigit levels in the G7 nations after 1995 and this can be traced to acceleration in the rate of decline of ICT prices. For example, the price index for computers and other data processing equipment fell from 140.5 in 1992 to 45.9 in $2000(1995=100)$ in the U.K. (ONS, 2003).

In his study of the effects of investment in ICT on productivity in the G7 economies, Jorgenson (2003) points out that national accounting statistics outside the U.S.A. underestimate the role played by ICT because of differences in the way it is measured. American 
statistics count firms' spending on software as investment so it contributes to Gross Domestic Product (GDP). In much of the rest of the world, most of it is counted as a current business expense and so excluded from final output.

The surge in spending on software in the late 1990s therefore inflated recorded investment and growth in America relative to that elsewhere. A second difference concerns the price deflators used to convert nominal spending on IT equipment into real terms. Official statistics in many European economies make less adjustment than in the U.S.A. for improvements in the quality of computers, causing an understatement of GDP growth relative to the U.S.A.'s. The evidence suggests that most of the industrial world's productivity growth in ICT-using industries lags behind the U.S.A.'s. There is also the issue that rigid labour markets prevent firms from taking full advantage of new technology, because it is harder to lay workers off and this blocks the reallocation of workers to more productive jobs.

\section{IS THERE A PRODUCTIVITY GAP BETWEEN THE UK AND ITS COMPETITORS?}

A report by the National Institute of Economic and Social Research (O'Mahoney and de Boer, 2002) presents estimates and relative levels and growth rates of labour productivity, capital intensity, skill intensity and TFP for various industry sectors including construction. One of the study's concerns is to discover which sectors have the greatest productivity gaps between the U.K. and its competitors. In evaluating productivity performance, they divide sectors in accordance with their use of ICT. Generally, underlying productivity performance is better in traditional industries than in ICT using/producing sectors.

In comparison with France and Germany (but not the U.S.A.), the U.K. fares well in the construction sector (Table 5) with a higher level of TFP.
Table 5. Relative TFP in Construction 1999

\begin{tabular}{llll}
\hline U.K. & U.S.A. & France & Germany \\
\hline 100 & 102 & 98 & 85 \\
\hline
\end{tabular}

(Source: O'Mahoney and de Boer, 2002)

The report indicated that some U.K. industries showed an acceleration of productivity growth in the latter half of the 1990s but that these were in the ICT intensive sectors. In contrast, there was deterioration in the TFP growth rate of construction in the second part of the 1990s but, as can be seen in Table 6, over the full period reviewed, the TFP rate was considerably higher in the U.K. than in the other countries.

Table 6. TFP growth rates $1989-1999$ (\% p.a. in construction

\begin{tabular}{llll}
\hline U.K. & U.S.A. & France & Germany \\
\hline 0.69 & -0.35 & -0.86 & -0.49 \\
\hline
\end{tabular}

(Source: O'Mahoney and de Boer, 2002)

\subsection{ICT shares}

The inter-country comparison also permits comparative analysis of the construction sector in terms of the use of ICT capital. Figure 7 shows various sectors' share of total ICT capital, averaged over the period 1995-99 for the U.S.A., U.K. and France. It indicates a similar picture across countries. The sectors, where ICT capital is used most are transport \& communications (TC) and financial \& business services (FBS). ICT capital is relatively important in manufacturing (Manuf) but of relatively little importance in construction (Const).

When linked to the BEA data (see Figure 4), this gives confirmation to the low-level of both investment and consequent ICT capital levels in the construction sector.

\section{CONCLUSIONS}

It is generally true that the impact of ICT has been widely analysed in other industry sectors but poorly understood in the construc- 


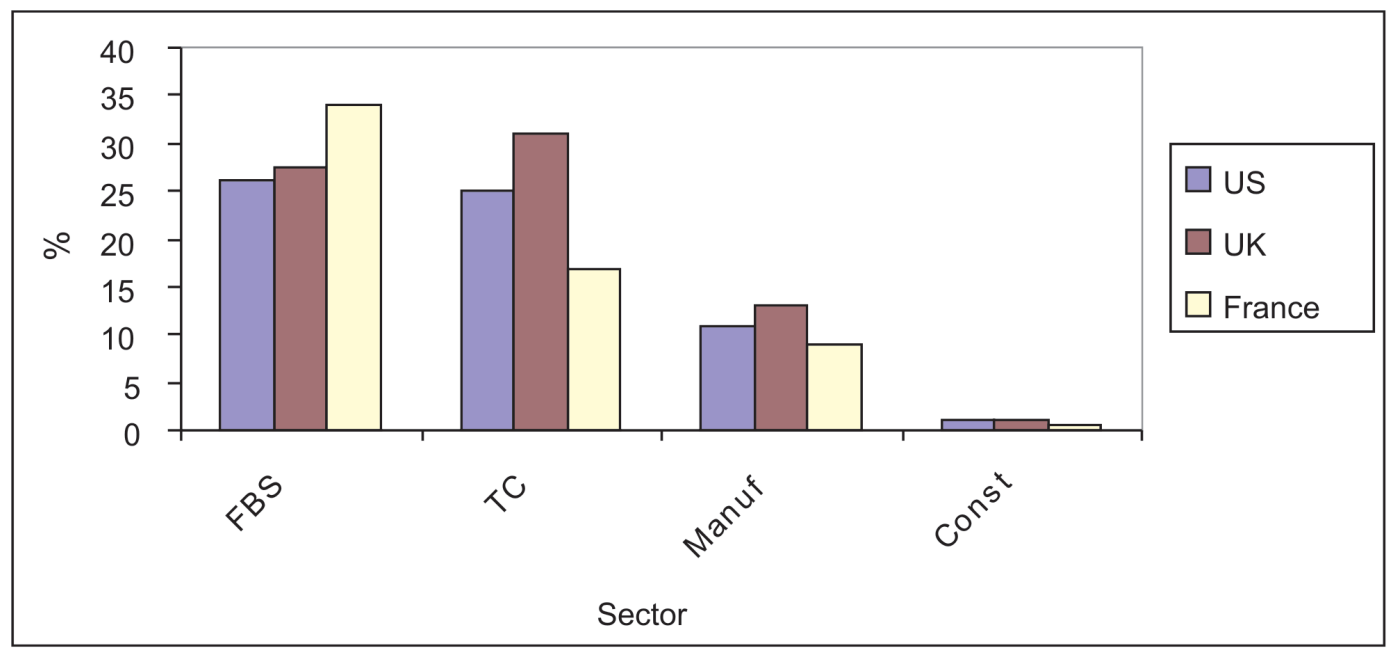

(Source: Adapted from O’Mahoney and de Boer, 2002)

Figure 7. Sectoral shares of ICT capital in the U.S., U.K. and France

tion industry. Investments in human capital and tangible assets, including ICT equipment and software, account for the overwhelming proportion of growth of the economic wealth created by an industry. The specific correlation between ICT investment in an industry and that industry's contribution to the economy is an important aspect of this relationship. U.K. and U.S. data indicate that there is a general pattern of lower use of and investment in ICT in the construction sector than in other industries but Milana and Zeli (2001) found that the impact of ICT on TFP was particularly strong.

Using Jorgenson's methodology for the evaluation of capital investment on economic growth, ICT has made a particularly strong contribution post-1995.

Over the period 1995-2000, ICT investment accounted for a contribution of almost $50 \%$ to growth in the U.K. construction industry. The fact that shorter-lived ICT assets are substituted for longer-lived ones means that, since 2000 , an even greater proportion of growth will have been attributable to such investment. Also, as Basu et al. (2003) discerned, this effect is exacerbated as TFP rises with time lags.

In spite of the relatively low level of invest- ment in ICT in the construction sector, there have been undoubted benefits to the industry in productivity terms from expenditure on computer services and investment in ICT capital.

The construction industry is particularly notable for its beneficial use of interactions-enabling technology. Gretton's et al work showed that this specific type of investment has a major impact on the construction sector.

It is true that the construction industry is different from many other sectors because firms tend to be 'under-financed' and, therefore, have limited capital for re-investment. Certainly it has been the case that productivity per worker has been increasing in the U.K., and coupled with declining employment in the industry, the provision of more ICT capital for each worker has undoubtedly improved efficiency.

\section{REFERENCES}

Basu, S., Fernald, J. G., Oulton, N. and Srinavasan, S. (2003) The Case of the Missing Productivity Growth: Or, Does Information Technology Explain Why Productivity Accelerated in the US but not in the UK? Working Paper No. W10010, National Bureau of Economic Research, Cambridge, US. 
Battese, G. E. and Coelli, T. J. (1998) Prediction of Firm-level Technical Efficiencies with a Generalised Frontier Production Function and Panel Data. Journal of Econometrics, 7, p. 185208.

Becchetti, L., Bedoya, D. A. L. and Paganetto, L. (2003) ICT investment, productivity and efficiency: Evidence at firm level using a stochastic frontier approach. CEIS Tor Vergeta, Research Paper Series, 10(29).

Bureau of Economic Analysis (2004) US Department of Commerce - Fixed Asset Tables, (www.bea.doc.gov).

CICA (1990) Building on IT for the 90s. A Survey of IT Trends and Needs in the Construction Sector, CICA. London.

Caves, D. W., Christensen, L. R. and Diewert, W. E. (1982) The Economic Theory of Index Numbers and the Measurement of Input, Output and Productivity. Econometrica, 50, p. 1393-1414.

David, P. A. (1990) The Dynamo and the Computer and Dynamo. A Historical Perspective on the Modern Productivity Paradox. American Economic Review Papers and Proceedings, 80(2), p. 355-361.

Färe, R., Grosskopf, S., Norris, M. and Zhang, Z. (1994) Productivity Growth, Technical Progress and Efficiency Changes in Industrialised Countries. American Economic Review, 84, p. 66-83.

Gretton, P., Gali, J. and Parham, D. (2002) Uptake and Impacts of ICT in the Australian Economy: Evidence from Aggregate, Sectoral and Firm Levels. Paper presented at the OECD Workshop on ICT and Business Performance. Productivity Commission, Canberra, 12.02.

Hochstrasser, B. and Griffiths, C. (1991) Controlling IT Investment - Strategy and Management, Chapman and Hall, London.

Jorgenson, D. W. (2003) Information Technology and the G7 Economies. World Economics, 4(4).
Lehr, B. and Lichtenberg, F. (1999) Information Technology and its Impact on Productivity. Firm-level evidence from Government and Private Data Sources. Canadian Journal of Economics, 32(2), p. 335-362.

Li, H., Irani, Z. and Love, P. (2000) The IT performance evaluation in the construction industry. Proceedings of the $33^{\text {rd }}$ Hawaii International Conference on System Sciences.

Milana, C. and Zeli, A. (2001) The Contribution of ICT to Production Efficiency in Italy: FirmLevel Evidence Using DEA and Econometric Estimations. STI Working Paper 2002/13, OECD, Paris.

OECD (2003) Measuring the Infrastructure Economy, at: www.oecd.org/dsti/sti/it/prod/index

O'Mahoney, M. and de Boer, W. (2002) Britain's Relative Productivity Performance: Updates to 1999. National Institute of Economic and Social Research.

ONS (1992, 1996, 2000) UK Input-Output Tables, Office for National Statistics, London.

ONS (2003) UK Input-Output Analyses, at: www.statistics.gov.uk/cci.

Schreyer, P. (2002) The Contribution of Information and Communication Technology Output Growth: A Study of the G7 Countries, OECD, Paris.

Skibniewski, M. J. and Park, S. (2003) Investing in IT: Impact on project and company finance. Proceedings of the INCITE 2004 Conference on Designing, Managing and Supporting Construction Projects Through Innovation and IT Solutions, Langkawi, Malaysia, 02/04.

Solow, R. M. (1987) We'd Better Watch Out. New York Times, July 12, Book Review No. 36.

Wyckoff, A. W. (1995) The Impact of Computer Prices on International Comparisons of Productivity. Economics of Innovation and New Technology, $3(3-4)$.

\section{SANTRAUKA}

\section{INFORMACINĖS IR KOMUNIKACIJU TECHNOLOGIJOS STATYBOS SEKTORIUJE: EKONOMINĖS NAUDOS SKAIČIAVIMAS}

\section{Les RUDDOCK}

Gana sunku nustatyti tikslią ekonominę naudą, kurią statybos sektorius gauna iš technologijų kaitos. Statybos sektoriaus įnašas ị valstybės ekonomiką didelis, todèl svarbu, kad technologijų kaitos poveikis šiai pramonès šakai būtų ịvertintas tinkamai. Šiame straipsnyje apžvelgiamas vienas iš technologinių šios šakos pokyčių - išaugę informacinių ir komunikacijos technologijų (IKT) naudojimo mastai. Darbe nagrinejjami argumentai, susiję su lemiamu IKT naudojimo vaidmeniu ir investavimu ị augimo skatinimą bei techninio našumo tobulinimą šioje šakoje. Svarstoma, kaip galima būtų vertinti iš IKT gaunamą naudą šakos lygmeniu. Šiame tyrime daugiausia dèmesio skiriama Jungtinès Karalystės statybos sektoriui, kuris lyginamas su kitų išsivysčiusių pramonės šalių statybos sektoriais. Analizės rezultatai rodo, kad statybos sektoriaus našumas pagaliau pradeda gauti naudos iš intensyvaus investavimo ị IKT, vykusio po 1995 metų. 